\title{
Guia prático de ultra-sonografia vascular
}

\author{
Carlos Alberto Engelhorn, Domingos de Moraes Filho, Fanilda Souto Barros, \\ Nostradamus Coelho (orgs.). Rio de Janeiro: DiLivros; 2007.
}

\begin{abstract}
Ricardo C.
A ultra-sonografia Doppler (ou eco-Doppler, ou, ainda, duplex scan) se tornou o mais importante método para o diagnóstico e planejamento cirúrgico da maioria das doenças vasculares. Atualmente, o eco-Doppler é usado em praticamente todos os problemas vasculares, sejam venosos ou arteriais. A avaliação das varizes e o diagnóstico da trombose venosa se resumem ao ecoDoppler. Nas doenças arteriais, a arteriografia foi substituída pelo eco-Doppler na avaliação das carótidas, dos aneurismas periféricos e da aorta abdominal. Mesmo no último reduto da arteriografia, que é a doença oclusiva dos membros inferiores, muitos cirurgiões experientes baseiam as decisões pré-operatórias e o planejamento cirúrgico no exame de eco-Doppler. Ou seja, nós, angiologistas/cirurgiões vasculares, tornamonos "ecodependentes" em nossa prática diária.
\end{abstract}

Quem acompanha o cenário da angiologia/cirurgia vascular do Brasil fica impressionado com o espetacular desenvolvimento da ultra-sonografia Doppler em nosso meio nestes últimos 15 anos. No início, eram apenas uns poucos entusiastas, de origens diversas: alguns eram angiologistas/cirurgiões vasculares, outros faziam ecografia geral, e outros, ainda, eram cardiologistas. O que todos tinham em comum era o entusiasmo e a disposição de investir tempo para dominar a nova técnica e dinheiro na aquisição dos novos equipamentos. $\mathrm{O}$ esforço desses pioneiros resultou na criação de uma nova especialidade médica no Brasil: a ultra-

Copyright $\odot 2007$ by Sociedade Brasileira de Angiologia e de Cirurgia Vascular. J Vasc Bras 2007;6(1):102-103. sonografia vascular. Atualmente, nós, angiologistas/ cirurgiões vasculares, temos à nossa disposição aparelhos e profissionais médicos habilitados para realizar ultra-sonografia de qualidade em praticamente todas as cidades de médio a grande porte do país.

Uma característica peculiar da ultra-sonografia em nosso país é o fato de os exames serem feitos integralmente pelos médicos especialistas e não por vascular technologists, como acontece nos EUA e na Europa. Entre nós, os médicos executam o exame, escolhem as imagens, interpretam-nas, escrevem e assinam o laudo. Essa prática torna os exames de eco-Doppler feitos no Brasil muito mais dirigidos às necessidades dos médicos solicitantes do que exames feitos por técnicos sem experiência clínica.

O recém-lançado livro Guia prático de ultrasonografia vascular é um belo exemplo de onde chegou a especialidade (ou melhor, a área de atuação) no Brasil. Escrito quase que integralmente por especialistas brasileiros, o livro oferece uma abordagem clara e concisa da prática da ultra-sonografia vascular.

Organizado em 19 capítulos, o livro tem formato grande, com impressão em papel cuchê e ilustrações em cores em quase todas as páginas. A qualidade das reproduções das imagens ultra-sonográficas é simplesmente primorosa. Por si só, a qualidade da apresentação gráfica já vale o preço do livro.

Mas o livro não tem só forma, tem também substância. O capítulo inicial oferece um resumo tão claro e conciso das bases físicas da ultra-sonografia que até um leigo consegue entender. Os outros capítulos cobrem 
todas as áreas anatômicas e clínicas de interesse vascular, das carótidas às doenças venosas dos membros inferiores. Alguns capítulos abordam assuntos que não são habitualmente cobertos por textos de ultrasonografia, como avaliação de transplantes renais, compressão extrínseca do tronco celíaco, síndrome do desfiladeiro torácico e varizes pélvicas. Em resumo, apesar de relativamente curto, com exatas 200 páginas, o livro cumpre a promessa expressa no título: ser um guia prático para o interessado em ultra-sonografia vascular.

Cabe aqui fazer um comentário a respeito da influência do Dr. Sérgio X. Salles-Cunha sobre os autores do livro. Engenheiro e pesquisador brasileiro radicado há décadas nos EUA, o Dr. Sérgio sempre manteve fortes vínculos com seu país de origem. Responsável pelo desenvolvimento de aparelhos e inovações técnicas desde o início da ultra-sonografia vascular, pode ser considerado uma espécie de figura paterna da ultrasonografia vascular do Brasil. Os autores todos podem ser considerados seus filhos intelectuais.

O Guia prático de ultra-sonografia vascular representa, para a comunidade vascular brasileira, a consolidação de uma maneira própria de fazer ultra-sonografia. O livro certamente será muito útil a todos que executam ou utilizam exames de eco-Doppler na sua prática diária, do residente ao veterano. 